Огляди літератури, оригінальні дослідження, погляд на проблему

УДК616.12- 008.331.1-091.8-06:616.89-008.46

DOI

\title{
ВПЛИВ СТРУКТУРНО-ФУНКЦІОНАЛЬНОГО СТАНУ СЕРЦЯ НА РОЗВИТОК КОГНІТИВНИХ ПОРУШЕНЬ У ХВОРИХ НА АРТЕРІАЛЬНУ ГІПЕРТЕНЗІЮ
}

๑О. В. Шманько

\author{
ДВНЗ «Тернопільський державний медичний університет імені І. Я. Горбачевського мОз України»
}

РЕЗЮМЕ. У 35 хворих на артеріальну гіпертензію досліджено вплив структурно-функціонального стану серця на стан когнітивних функцій. Оцінку когнітивного статусу проводили за допомогою короткої шкали оцінки психічного статусу (MMSE) та Монреальської шкали (MOCA). Стійкість уваги та швидкість сенсомоторних реакцій досліджували за таблицями Шульте. Якість життя пацієнтів оцінювали за фізичним і психічним компонентом за допомогою опитувальника SF-12. Всім хворим проводили ехокардіографічне обстеження з оцінкою товщини міжшлуночкової перетинки, товщини задньої стінки лівого шлуночка, кінцевого діастолічного розміру лівого шлуночка, розміру аорти і лівого передсердя, розмірів правого шлуночка і фракції викиду лівого шлуночка. Виявлено, що у хворих на АГ зниження фракції викиду лівого шлуночка визначає вираженість когнітивних розладів і сприяє погіршенню якості життя таких пацієнтів. Розвиток когнітивних порушень залежить також від розмірів лівого передсердя, товщини міжшлуночкової перегородки і задньої стінки лівого шлуночка та КДР лівого шлуночка. Не виявлено суттєвого впливу на когнітивний статус розмірів діаметра аорти та правого шлуночка.

КлЮчОВІ СлОВА: артеріальна гіпертензія, когнітивні функції, якість життя, структурно-функціональний стан серця.

Вступ. Проблема когнітивних розладів (КР) сьогодні набуває все більш актуального соціального значення і стає однією з основних проблем охорони здоров'я - «хворобою століття» або навіть «епідемією століття» $[4,8,23]$. Виявлення КР має проводитися за допомогою простих методик вже на амбулаторному етапі лікарями загальної практики-сімейної медицини та неврологами, тому що несвоєчасна діагностика на початковій стадії, як і відсутність адекватної терапії, призводять до їх подальшого прогресування. При цьому особливу увагу необхідно приділяти хворим, що належать до груп високого ризику розвитку КР [3, 7]. До таких належать хворі на артеріальну гіпертензію, оскільки ця хвороба $є$ важливим предиктором виникнення КР $[13,14]$. За даними ВООЗ, на сьогодні близько $25 \%$ дорослого населення світу хворіє на АГ, і за прогнозами, у 2025 році їх кількість зросте до 1,5 млрд. осіб [2] . Серед осіб похилого віку вона досягає 80 \%. Популяційними дослідженнями встановлено, що 80 \% літніх людей мають цереброваскулярні захворювання, а від 3 до $20 \%$ людей старше 65 років страждають на когнітивні розлади. Тому найбільш потужними чинниками ризику розвитку когнітивної дисфункції вважають саме похилий і старечий вік [5]. Основною причиною порушень когнітивних функцій вважа$\epsilon$ ться церебральна гіпоперфузія, що $є$ результатом розладів системної гемодинаміки Jelic [19]. Одні автори головною причиною зменшення мозкового кровообігу називають зниження серцевого викиду $[16,18]$. Інші пропонують розглядати ізольовано систолічну дисфункцію лівого шлуночка як гемодинамічний чинник, що призводить до церебральної гіпоперфузії [15]. Проте, за результатами досліджень ряду інших авторів, подібних закономірностей не виявлено $[6,17]$. Тому, не дивлячись на велику кількість робіт, присвячених вивченню КР судинного ґенезу, на сьогодні залишається недостатньо вивченою роль кардіальної патології у формуванні когнітивної дисфункції. Зважаючи на це, метою нашого дослідження було вивчення впливу структурно-функціонального стану серця за даними УзД на розвиток когнітивних розладів у хворих на АГ.

Матеріал і методи дослідження. Нами обстежено 35 пацієнтів з АГ 2-3 ступенів, які перебували на стаціонарному лікуванні у кардіологічному відділенні К3 ТОР «Тернопільська університетська лікарня». Серед них було чоловіків - 20 осіб і жінок 15 , середній вік склав - $(58,1 \pm 2,5)$ років, а середня тривалість захворювання становила $(11,5 \pm 1,0)$ років. Діагноз АГ був встановлений відповідно до клінічних рекомендацій з артеріальної гіпертензії Європейського товариства гіпертензії (ESH) та $\epsilon_{\text {B- }}$ ропейського товариства кардіологів (ESC) 2013 [9]. У кожного обстеженого отримано письмову згоду на участь в обстеженні. Дослідження виконували у спокійній обстановці, в окремій кімнаті, за відсутності інших осіб та відволікаючих факторів, тому що недотримання цих вимог може значно погіршити результати тестування. Когнітивні функції (КФ) визначали за допомогою нейропсихологічних тестів [1]. Використовували скринінговий метод діагностики когнітивного статусу за допомогою короткої шкали оцінки психічного статусу (MiniMental State Examination, MMSE) [20]. Також застосовували Монреальську шкалу (МОСА), яка дозволяє оцінити різні когнітивні сфери: увагу і концентрацію, виконавчі функції, пам'ять, мову, конструктивно-зорові навич- 
Огляди літератури, оригінальні дослідження, погляд на проблему ки, абстрактне мислення, рахування і орієнтацію [21]. Для оцінки стійкості уваги та швидкості сенсомоторних реакцій використовували методику таблиць Шульте $[1,11]$. Оцінку якості життя пацієнтів з АГ за фізичним і психічним компонентами проводили за допомогою опитувальника SF-12 [24 ]. Всім пацієнтам проводили також ехокардіографічне о6стеження (апарат «PHILIPS HD 11 XE») з оцінкою товщини міжшлуночкової перетинки (ТМШП, См), товщини задньої стінки лівого шлуночка (ТЗСЛШ, см), кінцевого діастолічного розміру лівого шлуночка (КДР, см), розміру аорти і лівого передсердя, розмірів правого шлуночка (см) і фракції викиду лівого шлуночка (ФВ ЛШ, \%).

Статистичну обробку результатів виконано у відділі системних статистичних досліджень університету в програмному пакеті Statsoft STATISTIKA. Для оцінки міжгрупових відмінностей застосовували параметричний t-критерій Стьюдента. Різницю між показниками вважали статистично достовірною при $p<0,05$.

Результати й обговорення. Аналіз результатів, наведених у таблиці 1, показав, що у хворих на АГ розмір діаметра аорти суттєво не впливав на стан когнітивних функцій, на що вказує лише тенденція до зниження показників MMSE i MOCА. Під час обстеження пацієнтів за допомогою таблиць Шульте спостерігали порушення розумової працездатності, уваги. Середні показники часу виконання завдань за таблицями Шульте в групі хворих на АГ з діаметром аорти >3,5 cм були відповідно на 5,0 \% більшими, порівняно 3 пацієнтами, у яких аорта мала діаметр < 3,3 см і на 50,2 \% - з показниками контрольної групи. Це свідчить про те, що у хворих на АГ при збільшенні діаметра аорти відзначається зниження уваги та швидкості сенсомоторних реакцій. Разом з тим, не було виявлено впливу розмірів аорти на показники фізичного і психічного компонентів якості життя, хоча вони у таких хворих достовірно зменшились, порівняно з контрольною групою.

Таблиця 1. Оцінка когнітивних функцій у хворих на артеріальну гіпертензію залежно від діаметра аорти $(\mathrm{M} \pm \mathrm{m})$

\begin{tabular}{|c|c|c|c|c|}
\hline \multirow{2}{*}{ Шкала } & \multicolumn{3}{|c|}{ Основна група, аорта, см } & \multirow{2}{*}{ Контрольна група } \\
\hline & $<3,3$ & $3,3-3,5$ & $>3,5$ & \\
\hline MMSE, бали & $23,64 \pm 0,52 \#$ & $24,15 \pm 0,58 \#$ & $22,85 \pm 0,45 \#$ & $27,75 \pm 0,51$ \\
\hline МОСА, бали & $24,71 \pm 0,61 \#$ & $25,25 \pm 0,60 \#$ & $23,95 \pm 0,49 \#$ & $28,10 \pm 0,40$ \\
\hline проба Шульте, с & $57,07 \pm 0,96 \#$ & $55,60 \pm 2,15 \#$ & $59,95 \pm 0,79 \# *$ & $39,92 \pm 0,93$ \\
\hline PCS, бали & $36,80 \pm 1,32 \#$ & $37,45 \pm 1,32 \#$ & $34,59 \pm 1,14 \#$ & $49,66 \pm 0,77$ \\
\hline MCS, бали & $35,03 \pm 1,29 \#$ & $37,21 \pm 1,46 \#$ & $33,45 \pm 1,07 \#$ & $50,53 \pm 0,85$ \\
\hline
\end{tabular}

Аналіз результатів, наведених у таблиці 2, показав, що розмір лівого передсердя $\epsilon$ чинником, який впливає на когнітивний статус хворих на АГ. Це підтверджують показники MMSE, які при його розмірі >4,0 см зменшились на 11,1\%, порівняно 3 хворими, у яких він був <3,5см. Це відповідає рівню помірних когнітивних розладів та деменції легкого ступеня вираженості відповідно. Також зростав час швидкості виконання завдань за таблицями Шуль- те, а саме на 5,8 \% при розмірі >4,0 см, порівняно 3 хворими, у яких він був <3,5 см. Нами встановлено зниження якості життя таких пацієнтів, про що свідчать показники фізичного і психічного компонентів, які зменшились, порівняно з контрольною групою. Слід зазначити вплив розміру лівого передсердя на показник психічного компонента якості життя пацієнтів з АГ, який зменшився на 8,1\% порівняно 3 хворими, у яких розмір був менше $3,5 \mathrm{~cm}$.

Таблиця 2. Оцінка когнітивних функцій у хворих на артеріальну гіпертензію залежно від розміру лівого передсердя $(\mathrm{M} \pm \mathrm{m})$

\begin{tabular}{|c|c|c|c|c|}
\hline \multirow{2}{*}{ Шкала } & \multicolumn{2}{|c|}{ Основна група, ліве передсердя, см } & \multirow{2}{*}{ Контрольна група } \\
\cline { 1 - 4 } & $<3,5$ & $3,5-4,0$ & $>4,0$ & \\
\hline MMSE, бали & $26,09 \pm 0,60 \#$ & $23,48 \pm 0,40 \#$ & $23,21 \pm 0,59 \# *$ & $27,75 \pm 0,51$ \\
\hline МОСА, бали & $25,27 \pm 0,96 \#$ & $24,55 \pm 0,41 \#$ & $24,29 \pm 0,62 \#$ & $28,10 \pm 0,40$ \\
\hline проба Шульте, с & $57,00 \pm 0,54 \#$ & $56,76 \pm 1,76 \#$ & $60,29 \pm 1,05 \# *$ & $39,92 \pm 0,93$ \\
\hline РСS, бали & $37,72 \pm 1,71 \#$ & $36,44 \pm 1,05 \#$ & $34,59 \pm 1,26 \#$ & $49,66 \pm 0,77$ \\
\hline MCS, бали & $36,45 \pm 0,76 \#$ & $35,63 \pm 1,11 \#$ & $33,22 \pm 1,01 \# *$ & $50,53 \pm 0,85$ \\
\hline
\end{tabular}

Примітки: 1. \# - p<0,05 по відношенню до контрольної групи; $2 .{ }^{*}-p<0,05$ по відношенню до групи хворих із лівим передсердям $<3,5$. 
Огляди літератури, оригінальні дослідження, погляд на проблему

Результати, наведені у таблиці 3, вказують на певну залежність когнітивних порушень від КДР лівого шлуночка у хворих на АГ. Зокрема, при розмірі >5,0 см показники шкал MMSE і MOCA знизились на 13,3 і 10,4 \% відповідно, порівняно $з$ контролем. Проте ми не виявили впливу зростання КДР лівого шлуночка на поглиблення когнітивних розладів, про що свідчать показники MMSE i МOCA, порівняно з хворими на АГ з розміром менше 4,5 см. Однак, оцінка уваги та сенсомоторних

реакцій показала, що у хворих з більшим КДР час виконання завдань за допомогою проби Шульте зріс на 51 \%, порівняно з контрольною групою і на 7,7 \% порівняно з пацієнтами з розміром КДР менше 4,5 см. Це свідчить про наявність певного взаємозв'язку між КДР лівого шлуночка і станом когнітивних функцій у хворих на АГ. Якість життя таких пацієнтів також була нижчою, порівняно 3 особами контрольної групи, проте вона не залежала від КДР лівого шлуночка.

Таблиця 3. Оцінка когнітивних функцій у хворих на артеріальну гіпертензію залежно від КДР лівого шлуночка $(\mathrm{M} \pm \mathrm{m})$

\begin{tabular}{|c|c|c|c|c|}
\hline \multirow{2}{*}{ Шкала } & \multicolumn{2}{|c|}{ Основна група, КДР лівого шлуночка, см } & \multirow{2}{*}{ Контрольна група } \\
\cline { 1 - 4 } & $<4,5$ & $4,5-5,0$ & $>5,0$ & \\
\hline MМSЕ, бали & $23,48 \pm 0,60 \#$ & $23,00 \pm 0,51 \#$ & $24,06 \pm 0,43 \#$ & $27,75 \pm 0,51$ \\
\hline МОСА, бали & $24,48 \pm 0,65 \#$ & $24,20 \pm 0,55 \#$ & $25,17 \pm 0,46 \#$ & $28,10 \pm 0,40$ \\
\hline проба Шульте, с & $52,43 \pm 1,08 \#$ & $58,20 \pm 1,96 \#$ & $56,50 \pm 0,97 \# *$ & $39,92 \pm 0,93$ \\
\hline РСS, бали & $35,94 \pm 1,35 \#$ & $35,31 \pm 0,86 \#$ & $37,31 \pm 1,41 \#$ & $49,66 \pm 0,77$ \\
\hline MСS, бали & $35,10 \pm 1,38 \#$ & $34,23 \pm 1,17 \#$ & $36,23 \pm 1,35 \#$ & $50,53 \pm 0,85$ \\
\hline
\end{tabular}

Примітки: 1. \# - р<0,05 по відношенню до контрольної групи; 2. * - р<0,05 по відношенню до групи хворих із КдР лівого шлуночка $<4,8$.

Нами встановлено, що товщина міжшлуночкової перегородки (ТМШП) і товщина задньої стінки лівого шлуночка (ТЗСЛШ) мають певний вплив на когнітивний статус хворих на АГ (табл. 4, 5). Зокрема, збільшення розмірів ТМШП >1,25 см і ТЗСЛШ>1,35 м призводить відповідно до зниження показника MMSE на 16,8 і $17,8 \%$, порівняно 3 контрольною групою, та на 12,0 і 12,1 \% порівняно з хворими, у яких ТМШП і ТЗСЛШ була <1,15 см. Що стосується показників Монреальської шкали (МОСА), то вони були достовірно нижчими, порівняно з контрольною групою, проте не спостерігалось їх значних змін залежно від товщини міжшлуночкової перегородки та задньої стінки лівого шлуночка. Однак, такий взаємозв'язок ми виявили, оцінюючи пробу Шульте, яка зросла на 22,7 і 15,2 \% відповідно у пацієнтів з ТМШП >1,25 см і ТЗСЛШ >1,35 см порівняно з хворими, у яких ТМшП і ТЗСлш була $<1,15$ см. Також виявлено зниження якості життя таких пацієнтів, про що свідчать показники фізич- ного і психічного компонентів, які зменшились, порівняно з контрольною групою. Слід відмітити, що товщина задньої стінки лівого шлуночка має виражений вплив на ці параметри якості життя пацієнтів з АГ, які зменшились відповідно на 9,6 і 8,8 \% при збільшенні ТЗСЛШ >1,35 см, порівняно з хворими, у яких вона була менше 1,15 см. Виявлений нами вплив ТМШП і ТЗСЛШ на розвиток когнітивних порушень у хворих на АГ у певній мірі узгоджується з результатами С. М. Стадніка, який встановив кореляційний зв'язок між ступенем вираженості когнітивного дефіциту та такими показниками, як розміри МШП і товщина ЗСлШ у пацієнтів з дисциркуляторною енцефалопатією на фоні атріовентрикулярної блокади [12].

Аналіз результатів, наведених у таблиці 6, свідчить про незначну залежність когнітивних порушень від розмірів правого шлуночка у хворих на АГ. Зокрема, при розмірі >2,4 см показники шкал MMSE і MOCA знизились відповідно на 11,9 і 9,7\%, порівняно з контролем. Проте нами не ви-

Таблиця 4. Оцінка когнітивних функцій у хворих на артеріальну гіпертензію залежно від товщини міжшлуночкової перегородки $(\mathrm{M} \pm \mathrm{m})$

\begin{tabular}{|c|c|c|c|c|}
\hline \multirow{2}{*}{ Шкала } & \multicolumn{2}{|c|}{ Основна група, міжшлуночкова перегородка, см } & \multirow{2}{*}{ Контрольна група } \\
\cline { 2 - 4 } & $<1,15$ & $1,15-1,25$ & $>1,25$ & \multirow{2}{*}{$27,75 \pm 0,51$} \\
\hline MMSЕ, бали & $26,25 \pm 0,54 \#$ & $23,94 \pm 0,44 \#^{*}$ & $23,10 \pm 0,50 \#^{*}$ & $28,10 \pm 0,40$ \\
\hline МОСА, бали & $24,25 \pm 0,66 \#$ & $25,10 \pm 0,45 \#$ & $23,73 \pm 0,65 \#$ & $39,92 \pm 0,93$ \\
\hline проба Шульте, с & $48,75 \pm 1,75 \#$ & $56,58 \pm 1,50 \#$ & $59,82 \pm 1,44 \# *$ & $49,66 \pm 0,77$ \\
\hline РСS, бали & $35,68 \pm 1,88 \#$ & $37,30 \pm 0,94 \#$ & $33,77 \pm 1,27 \#$ & $50,53 \pm 0,85$ \\
\hline MCS, бали & $39,10 \pm 1,01 \#$ & $35,97 \pm 1,04 \#$ & $33,37 \pm 1,05 \# *$ & \\
\hline
\end{tabular}

Примітки: 1. \# - p<0,05 по відношенню до контрольної групи; 2. * - p<0,05 по відношенню до групи хворих із міжшлуночковою перегородкою $<1,15$. 
Огляди літератури, оригінальні дослідження, погляд на проблему

Таблиця 5. Оцінка когнітивних функцій у хворих на артеріальну гіпертензію залежно від товщини задньої стінки лівого шлуночка $(\mathrm{M} \pm \mathrm{m})$

\begin{tabular}{|c|c|c|c|c|}
\hline \multirow{2}{*}{ Шкала } & \multicolumn{3}{|c|}{ Основна група, задня стінка лівого шлуночка, см } & \multirow{2}{*}{ Контрольна група } \\
\hline & $<1,15$ & $1,15-1,35$ & $>1,35$ & \\
\hline MMSE, бали & $25,93 \pm 0,50 \#$ & $23,60 \pm 0,46 \#$ & $22,80 \pm 0,57 \#^{*}$ & $27,75 \pm 0,51$ \\
\hline МOСА, бали & $24,93 \pm 0,61 \#$ & $24,77 \pm 0,48 \#$ & $23,80 \pm 0,63 \#$ & $28,10 \pm 0,40$ \\
\hline проба Шульте, с & $52,79 \pm 1,19 \#$ & $57,13 \pm 1,58 \#$ & $60,80 \pm 1,24 \#^{*}$ & $39,92 \pm 0,93$ \\
\hline PCS, бали & $37,43 \pm 1,00 \#$ & $36,64 \pm 0,91 \#$ & $33,85 \pm 0,89 \# *$ & $49,66 \pm 0,77$ \\
\hline MCS, бали & $36,21 \pm 1,13 \#$ & $35,54 \pm 1,10 \#$ & $33,03 \pm 0,60 \# *$ & $50,53 \pm 0,85$ \\
\hline
\end{tabular}

Таблиця 6. Оцінка когнітивних функцій у хворих на артеріальну гіпертензію залежно від розміру правого шлуночка $(\mathrm{M} \pm \mathrm{m})$

\begin{tabular}{|c|c|c|c|c|}
\hline \multirow{2}{*}{ Шкала } & \multicolumn{2}{|c|}{ Основна група, правий шлуночок, см } & \multirow{2}{*}{ Контрольна група } \\
\cline { 2 - 4 } & $<2,0$ & $2,0-2,4$ & $>2,4$ & \\
\hline MМSЕ, бали & $23,35 \pm 0,53 \#$ & $23,17 \pm 0,50 \#$ & $24,46 \pm 0,53 \#$ & $27,75 \pm 0,51$ \\
\hline МОСА, бали & $24,59 \pm 0,60 \#$ & $24,25 \pm 0,53 \#$ & $25,38 \pm 0,56 \#$ & $28,10 \pm 0,40$ \\
\hline проба Шульте, с & $58,88 \pm 1,81 \#$ & $58,13 \pm 1,84 \#$ & $55,46 \pm 2,52 \#$ & $39,92 \pm 0,93$ \\
\hline РСS, бали & $35,33 \pm 1,05 \#$ & $35,34 \pm 0,98 \#$ & $39,01 \pm 1,96 \#$ & $49,66 \pm 0,77$ \\
\hline МСS, бали & $34,12 \pm 1,10 \#$ & $34,90 \pm 1,10 \#$ & $37,37 \pm 1,97 \#$ & $50,53 \pm 0,85$ \\
\hline
\end{tabular}

Примітки: 1. \# - p<0,05 по відношенню до контрольної групи; $2 .{ }^{*}-$ p<0,05 по відношенню до групи хворих із правим шлуночком $<2,0$.

явлено впливу зростання його розмірів на глибші зміни когнітивного статусу, порівняно з хворими на АГ з розміром менше 2,0 см. Щодо оцінки уваги та сенсомоторних реакцій, то у хворих з більшим розміром правого шлуночка час виконання завдань за допомогою проби Шульте достовірно зріс, порівняно з контрольною групою, проте він не залежав від змін його величини. Якість життя таких пацієнтів була нижчою, порівняно з особами контрольної групи, хоча розміри правого шлуночка також суттєво на неї не впливали.

Як свідчать результати, представлені у таблиці 7, зниження показників фракції викиду лівого шлуночка (ФВ ЛШ) сприяє поглибленню когнітивних розладів у хворих на АГ. Так, у хворих на АГ з ФВ ЛШ 50-59 \% спостерігається зменшення показників MMSE і МОСА відповідно на 14,2 і 8,1\%, а з ФВ ЛШ $\leq 50 \%$ - на 13 і 10,3 \%, порівняно з пацієнтами, у яких ФВ ЛШ була $\geq 60$ \%. Подібні зміни були виявлені і при оцінці часу виконання завдань за допомогою проби Шульте, що збільшився на $36,6 \%$ у пацієнтів з ФВ ЛШ 50-59 \% та на $40 \% 3$ ФВ лШ $\leq 50 \%$. Це свідчить про взаємозв'язок між величиною фракції викиду ЛШ та когнітивним статусом у хворих на АГ. Виявлені когнітивні порушення сприяли погіршенню якості життя таких пацієнтів, на що вказують показники психічного і фізичного компонентів. Зокрема, вони відповідно знизились у хворих з ФВ ЛШ 50-59 \% і ФВ ЛШ $\leq 50 \%$ - на 29,2 і $31 \%$ та на 28 і 30,1\%.

Таблиця 7. Оцінка когнітивних функцій у хворих на артеріальну гіпертензію залежно від фракції викиду (Мџm)

\begin{tabular}{|c|c|c|c|c|}
\hline \multirow{2}{*}{ Шкала } & \multicolumn{3}{|c|}{ Основна група, фракція викиду, \% } & \multirow{2}{*}{ Контрольна група } \\
\cline { 2 - 4 } & $\geq 60$ & $59-50$ & $\leq 50$ & \\
\hline ММSЕ, бали & $26,63 \pm 0,56$ & $22,84 \pm 0,51 \#^{*}$ & $23,18 \pm 0,47 \#^{*}$ & $27,75 \pm 0,51$ \\
\hline МОСА, бали & $25,92 \pm 0,60$ & $23,84 \pm 0,56 \#$ & $23,24 \pm 0,50 \#^{*}$ & $28,10 \pm 0,40$ \\
\hline проба Шульте, с & $43,29 \pm 1,15 \#$ & $59,16 \pm 1,90 \#^{*}$ & $60,59 \pm 1,10 \#^{*}$ & $39,92 \pm 0,93$ \\
\hline РСС, бали & $48,65 \pm 1,15$ & $35,05 \pm 1,10 \#^{*}$ & $33,99 \pm 1,06 \#^{*}$ & $49,66 \pm 0,77$ \\
\hline МСS, бали & $47,91 \pm 1,22 \#$ & $33,90 \pm 1,13 \#^{*}$ & $33,08 \pm 1,14 \#^{*}$ & $50,53 \pm 0,85$ \\
\hline
\end{tabular}

Примітки: 1. \# - p<0,05 по відношенню до контрольної групи; 2. * - p<0,05 по відношенню до групи хворих із фракцією викиду $\geq 60$.

Виявлені нами когнітивні розлади у хворих на АГ зі зниженою фракцією викиду лШ в певній мірі підтверджуються результатами інших дослідників, які встановили зв'язок між когнітивною дисфункцією та ХCH, а саме той факт, що серед пацієнтів з КР частіше виявляється ХCH, ніж серед когнітивно збережених осіб [22]. На нашу думку, прямий вплив порушеної фракції викиду (ФВ) лівого шлуночка (ЛШ) на об'ємний кровотік в артеріях каротидної системи призводить до виснаження церебральної ауторегуляції, викликає церебральну гіпоперфузію іє причиною розвитку 
Огляди літератури, оригінальні дослідження, погляд на проблему

когнітивних розладів. Також слід відмітити, що при судинній мозковій недостатності найбільш вразливими $\epsilon$ пам'ять і увага внаслідок розвитку гіпоперфузії у глибинних відділах білої речовини головного мозку та базальних гангліїв з формуванням синдрому «відокремлення» лобних часток головного мозку та підкіркових утворень [10].

Висновки. 1.У хворих на артеріальну гіпертензію встановлено, що зниження фракції викиду лівого шлуночка визначає вираженість когнітивних розладів і сприяє погіршенню якості життя таких пацієнтів за показниками психічного і фізичного компонентів.

\section{ЛІТЕРАТУРА}

1. Вассерман Л. И. Методы нейропсихологической диагностики : практическое руководство / Л. И. Вассерман, С. А. Дорофеева, Я. А. Меерсон. - СПб. : Стройлеспечать, 1997. - 34 с.

2. Всемирная организация здравоохранения (2011) План действий по Европейской стратегии профилактики и борьбы с неинфекционными заболеваниями, 2012-2016 гг. Европейский региональный комитет ВОЗ. Шестьдесят первая сессия. - Азербайджан, Баку, 12-15 сентября. -5 с.

3. Джеймс Ф. Тул. Сосудистые заболевания головного мозга / Джеймс Ф. Тул. - М. : ГЭОТАР-Медиа, 2007. -608 c.

4. Евстигнеев В. В. Когнитивные нарушения В неврологической практике / В. В. Евстигнеев. - Минск : Белпринт, 2009. - С. 45-52.

5. Захаров В. В. Нарушения памяти / В. В. Захаров, Н. Н. Яхно. - М. : ГеотарМед, 2003. - 150 С.

6. Захаров В. В. Когнитивные расстройства в пожилом и старческом возрасте : метод. пособие для врачей / В. В. Захаров, Н. Н. Яхно. - М., 2005. - 71 с.

7. Захаров В. В. Всероссийская программа исследований эпидемиологии и терапии когнитивных расстройств в пожилом возрасте («Прометей») / В. В. Захаров // Невролог. журн. - 2006. - Т. 11. - С. 27-32.

8. Зверева 3. Ф. Клинические и нейрофизиологические показатели у больных с дисциркуляторной энцефалопатией / З. Ф. Зверева // Журнал неврологии и психиатрии им. С. С. Корсакова. - 2010. - № 2. - С. 15-18.

9. Клінічні рекомендації з артеріальної гіпертензії Європейського товариства гіпертензії (ESH) та Європейського товариства кардіологів (ESC) 2013 року. - К., 2014.- 192 c.

10. Лагода О. В. Лечение нарушений памяти у больных с сосудистыми заболеваниями головного мозга / О. В. Лагода // Русский медицинский журнал. Неврология. Психиатрия. - 2004. - № 22. - С. 12-14.

11. Алгоритм прогнозирования развития когнитивных нарушений у больных с артериальной гипертензией и атеросклерозом коронарныхицеребральных артерий / Н. К. Мурашко, Т. П. Парникоза, Г. Н. Чуприна, Р. В. Сулик [и др.] : методические рекомендации. -Киев, 2014. - 40 с.
2. Розвиток когнітивних порушень у хворих на артеріальну гіпертензію залежить від розмірів лівого передсердя, товщини міжшлуночкової перегородки і задньої стінки лівого шлуночка та КДР лівого шлуночка.

3. Не виявлено суттєвого впливу на когнітивний статус у хворих на артеріальну гіпертензію розмірів діаметра аорти та правого шлуночка.

Перспективи подальших досліджень. Дослідження когнітивних функцій у хворих на артеріальну гіпертензію може бути використане для ранньої діагностики когнітивних порушень у таких пацієнтів та їх профілактики і лікування, а також для запобігання розвитку судинної деменції.

12. Стаднік С. М. Прогностичні критерії прогресування когнітивних розладів у пацієнтів з дисциркуляторною енцефалопатією на фоні атріовентрикулярної блокади / С. М. Стаднік // Ліки України. - 2014. - № 4 (21). - С. 10-14.

13. Старчина Ю. А. Когнитивные функции и эмоциональное состояние больных, перенесших инсульт, на фоне антигипертензивной терапии / Ю. А. Старчина, В. А. Парфенов, И. Е. Чазова // Журн. неврол. и психиат. им. С. С. Корсакова. Инсульт. - 2005. - Вып. 15. - С. 39-44.

14. Практическая кардионеврология / 3. А. Суслина, А. В. Фонякин [и др.] // ИМА-ПРЕСС, 2010. - 304 с.

15. Prevalence of DiagnosedAtrial Fibrillation in Adults / Alan S. Go, Elaine M. Hylek, Kathleen A. Phillips [et al.] // JAMA. - 2001. - Vol. 285, № 7. - P. 2370-2375.

16. Boss Ch. J. Is atrial fibrillation an inflammatory disorders? / Ch. J. Boss, R. A. Anderson, G.Y.H. Lip // Eur. Heart. J. - 2006. - Vol. 27. - P. 136-149.

17. The role of blood pressure in cognitiveimpairment in an elderly population / F. Cacciatore, P. Abete, N. Ferrara [et al.] // J. of Hypertension. - 2002. - Vol. 15. P. 0135-0142.

18. Engelmann M. D. M. Inflammation in the genesis of atrial fibrillation / M. D. M. Engelmann, J. H. Svedsen // Eur. Heart. J. - 2005. - Vol. 20 (26). - P. 2083-2092.

19. Jelic V. Clinical trials in mild cognitive impairment: lessons for the future / V. Jelic, M. Kivipelto, B. Winblad // J. Neurology Neurosurgery Psychiatry. - 2006. -Vol. 77. 892 p.

20. Folstein M. F. Mini Mental State: A practical method for grading the cognitive state of patients for the clinician / M. F. Folstein, S. E. Folstein, P. R. McHugh // Journal of Psychiatric Research. - 1975. - № 12 (3). - P. 189-198.

21. Nasreddine Ziad S., Phillips Natalie A., Bédirian Valérie, Charbonneau Simon, Whitehead Victor, Collin Isabelle, Cummings Jeffrey L., Chertkow Howard. The Montreal Cognitive Assessment, MoCA: A Brief Screening Tool For Mild Cognitive Impairment. - 2005. - Vol. 53(4). P. 695-699.

22. Pullicino P. M. Cognitive Impairment in congestive heart failure / P. M. Pullicino, J. Hart // Neurology. - 2001. Vol. 57. - P. 1945-1946. 
Огляди літератури, оригінальні дослідження, погляд на проблему

23. Skoog I. Clinical trials for primary prevention in dementia / I. Skoog, D. Gustafson // Dementia therapeutic research. - 2006. - P. 189-212.
24. Ware J. E. A 12-Item Short-Form Health Survey: Construction of scales and preliminary tests of reliability and validity / J. E. Ware, M. Kosinski, S. D. Keller // Medical Care. - 1996. - Vol. 34 (3).- P. 220-233.

\title{
THE IMPACT OF STRUCTURAL AND FUNCTIONAL STATE OF THE HEART ON THE DEVELOPMENT OF COGNITIVE IMPAIRMENT IN PATIENTS WITH HYPERTENSION
}

\section{O. V. Shmanko}

\author{
SHEI «Temopil State Medical University by I. Ya. Horbachevsky of MPH of Ukraine»
}

SUMMARY. In 35 patients with hypertension the influence of structural and functional state of the heart on the state of cognitive functions was examined. Assessment of cognitive status was performed using short scale assessment of mental status (MMSE) and Montreal scale (MOCA). Sustainabilityof attention and speed of sensorimotor reactions were investigated using the tables of Schulte. The quality of life of patients was evaluated for physical and mental component using a questionnaire SF-12. All patients underwent echocardiographic examination with assessment of interventricular septum thickness, posterior wall thickness of the left ventricle, end-diastolic size of the left ventricle, the size of the aorta and left atrium, right ventricular dimensions and left ventricular ejection fraction. It was found that in patients with hypertension reduction in left ventricular ejection fraction determines the severity of cognitive impairment and promotes worsening of the quality of life in these patients. The development of cognitive impairment also depends on the size of the left atrium, interventricular septum thickness and posterior wall of the left ventricle and left ventricle end-diastolic size. There was no significant effect of the diameter of aorta and the right ventricle size on the cognitive status.

KEY WORDS: hypertension, cognitive function, quality of life, structural and functional heart condition.

Отримано 18.06.2015 